\title{
Competitive Advantages as a Complete Mediator Variable in Strategic Resources, Dynamic Capabilities and Performance Relations in the Car Sales Sector
}

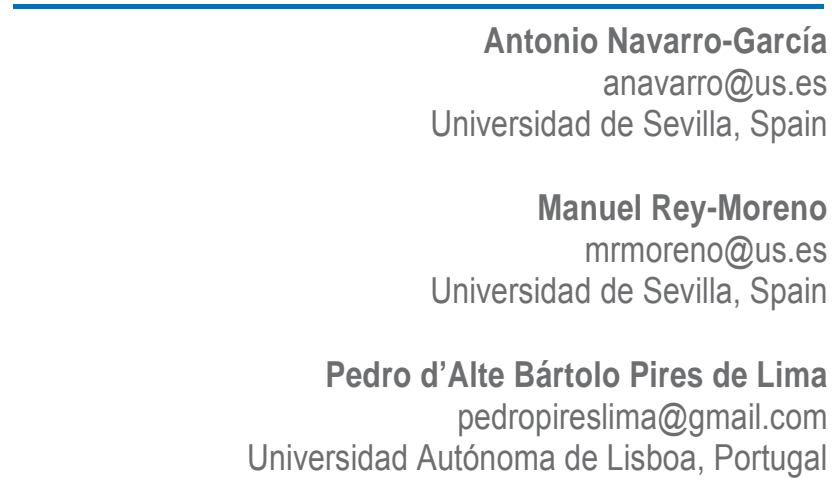

\begin{abstract}
Taking the resource-based view -RBV- and the dynamic capability view -DCV- as an orientation, the main aim of this study is to develop the mediator role that competitive advantages play in the relations between strategic resources, dynamic capabilities and performance. The study takes place in a dynamic and changing sector: the sale of new cars in Portugal. The results show that (a) achieving competitive advantages, which are decisive for business results, depends on the available strategic resources and the generating of dynamic capabilities, (b) in dynamic and changing sectors strategic resources are essential to generate dynamic capabilities, (c) firms must center their attention on, more than results, the generating of sustainable competitive advantages as these act as a mediator variable of the effect of strategic resources and dynamic capabilities on performance. The data scrutiny uses structural equation modeling (SEM) through PLS as the statistical instrument. The sample comprises 89 firms which sell new cars in Portugal.
\end{abstract}

Keywords: Strategic resources, dynamic capabilities, competitive advantages, performance, car sales sector. 
Navarro-García, A., Rey-Moreno, M. \& Pires de Lima, P.DA.B. (2018) Competitive Advantages as a Complete Mediator Variable in Strategic Resources, Dynamic Capabilities and Performance Relations in the Car Sales Sector. Journal of Business, Universidad del Pacífico (Lima, Peru) Vol.10(1): 24-37

\section{Introduction}

The crisis that, at the European level, has affected the sector of the sale of new cars in the last decade, brought about especially by a decrease in the demand, has produced intense changes in the sector, turning it into one of the most dynamic sectors of the European economies (Nicolini, Scarpa, \& Valbonesi, 2016). These changes have taken place in Portugal, where the postulates of the traditional paradigm of the Industrial Economy (Capron \& Hulland, 1999) do not appear to be sufficient to explain the strategic decision making and the business results. As a result, the following question arises: How do we explain that different firms which compete in the same market can obtain significantly distinct performances? The explanation is in the use made of strategic resources and the generating of dynamic capabilities (Lin \& Wu, 2014).

In this context, the resource-based view (RBV) points out that the accumulation and use of valuable, rare, inimitable and non-substitutable resources is the basis of business competitiveness and economic performance (Barney, 1991). Newbert (2008) also suggests that a relationship exists between value and rare resources and competitive advantages, and that competitive advantages are related to performance. These strategic resources can be of different types - information systems, infrastructures, etc.and they drive the development of the business capabilities and skills which enable the firm to compete with guarantees in the sector. That said, in accordance with the dynamic capability view (DCV) the mere possession and use of these strategic resources may be insufficient to achieve cost advantages or a differentiated positioning in the market. To do so, one must take into account the sector's dynamism, orienting the organization to the generation of capabilities which dynamically allow the combating of threats and an appropriate response to the changes that may occur in the sector (Wilden, Gudergan, Nielsen, \& Lings, 2013).

From this perspective, the premises of the RBV and the DCV indicate that strategic resources and dynamic capabilities tend to have a direct impact on both the achievement of competitive advantages and performance. However, the literature is not conclusive about the following question: Must an orientation of strategic resources and dynamic capabilities mainly toward the achieving of sustainable competitive advantages exist in the sector where the firm competes, or must an orientation exist toward business results, or must one take both aspects jointly into account? To fill this research gap is the main aim of this present work, doing so, what is more, in a country -Portugal- and a sector car sales- where the effects of the crisis have been very marked and where the need to generate competitive advantages from strategic resources and the capabilities available has become essential for survival and business growth.

This study has three main contributions. First, the study shows that in dynamic and changing environments, organizations must orientate themselves strategically toward the achievement of sustainable competitive advantages and not the business result in itself. Firms must know that competitive advantages play an essential role as a mediator variable in the relation between strategic resources-dynamic capabilities and business results. Second, the application of the principles of the RBV shows that the possession and use of strategic resources are essential to generate dynamic capabilities, positively contributing to the achieving of sustainable competitive advantages in costs, differentiation and staff efficiency. Finally, associated with the DCV which considers that dynamic capabilities are neither standard nor universal, the study demonstrates that to appropriately know the reality of the sector is essential to generate the necessary dynamic capabilities which enable the firm to compete in an advantageous position compared to its competitors. 
Navarro-García, A., Rey-Moreno, M. \& Pires de Lima, P.DA.B. (2018) Competitive Advantages as a Complete Mediator Variable in Strategic Resources, Dynamic Capabilities and Performance Relations in the Car Sales Sector. Journal of Business, Universidad del Pacífico (Lima, Peru) Vol.10(1): 24-37

This paper has four further sections. Following this introduction, the second section lays out the theoretical framework of the research as a reference to the principles of the RBV and DCV, proposing the conceptual model and hypotheses. The third section expounds the research methodology, details of the sample, and the data analysis tools for the empirical analysis. The fourth section presents the results and the main conclusions and managerial implications of these results.

\section{Theoretical Background and Research Hypotheses}

\section{Strategic Resources}

Since the beginning of the $90 \mathrm{~s}$, the RBV has emerged as a key perspective to organize and explain the determinants of the organizational result. Historically, the term resources has been used by academics either to refer to the inputs used in organizational processes - production, commercial, etc.- or as assets which the firm has to carry out its strategy (Crook, Ketchen, Combs, \& Todd, 2008). However, not all resources are strategic (Barney \& Arikan, 2001), as to be strategic they must be valuable, generating cost reductions or increasing the value for customers, rare or unique in such a way that the competitors cannot possess them or only do so with great difficulty, and hard to imitate or substitute. These strategic resources can be both tangible (for example, installations, financial resources) and intangible (for instance, information systems, human capital) (Grant, 1996). This research considers six types of strategic resources, three of them tangible - installations and equipment, stocks and financial resources- and three intangible - knowledge, professional experience and the training level of the human capital.

Nonetheless, in complex and quickly changing environments, the isolated use of these strategic resources only enables the development of specific activities in a firm, being able to increase their usefulness if they are are combined and managed for the generation of skills and organizational routines. These skills and routines dynamically facilitate adaptation and competence in the environment in which the firm acts (Wu, 2010). In this sense, strategic resources tend to be the origin of dynamic capabilities. These arguments lead to the proposal of the following research hypothesis:

$\mathrm{H1}$ : Strategic resources have a direct and positive effect on the generation of dynamic capabilities.

The RBV also points out that firms must accentuate the importance of the value of resources as sources of competitive advantages at the expense of a product-centered approach (Barney, Ketchen, \& Wright, 2011). In this context, the RBV focuses on how a sustained competitive advantage is generated by the unique bundle of resources at the core of the firm (Barney, 1991).

Yet though arguments exist in the literature which consider that the possession and use of specific resources can endow the firm with competitive advantages, fulfilling four conditions is necessary for this situation to occur (Powalla, 2012): (a) the available resources enable the firm to efficiently react in the face of the threats and opportunities 
Navarro-García, A., Rey-Moreno, M. \& Pires de Lima, P.DA.B. (2018) Competitive Advantages as a Complete Mediator Variable in Strategic Resources, Dynamic Capabilities and Performance Relations in the Car Sales Sector. Journal of Business, Universidad del Pacífico (Lima, Peru) Vol.10(1): 24-37

which arise ; (b) a small number of firms in the sector must possess and control these resources ; (c) the firms which do not have them suffer cost disadvantages when they try to obtain them; (d) these resources bring about a differentiated positioning in the market. The fulfillment of these four conditions concerns the strategic resources being able to endow the firm with temporary competitive advantages (Kozlenkova, Samaha, \& Palmatier, 2014). If, as well, the strategic resources are difficult to imitate or the cost of doing so is practically unbearable for the competitors, the temporary competitive advantages can be sustainable over time (Netland \& Aspelund, 2013). Therefore, the proposal of the following research hypothesis is:

$\mathrm{H} 2$ : Strategic resources have a direct and positive effect on the generation of competitive advantages.

On the other hand, the RBV addresses the central issue of how firms can achieve superior performance relative to other firms in the same market and posits that superior performance results from acquiring and exploiting valuable, rare, inimitable and nonsubstitutable firm resources (Dhanaraj \& Beamish, 2003). Specifically, the RBV recognizes the importance of internal determinants, and views firm-specific resources as the cornerstone of firm performance (Barney, 1991).

From this perspective, heterogeneity in the resources explains variations in firm performance (Makadok, 2001). In this context, Crook et al. (2008) conclude in their metaanalysis that possessing strategic resources has a direct influence, although as a moderator, on the business result. In any case, the finality in the use of resources and business capabilities must not be the result in itself. The aim must be the achievement of sustainable competitive advantages, the explanation being the direct moderator effect of the resources on the business results. What is more, Crook et al. (2008) point out that in complex and dynamic environments - as occurs in the present research with the sector of car sales - when the focus of the firm is the generation of competitive advantages, these act as a mediator variable between the resources - and the capabilities - and the business results; a direct relation between strategic resources and results does not exist. These arguments support the following research hypothesis:

H3: Strategic resources positively influence, although indirectly through the competitive advantages, the business results.

\section{Dynamic Capabilities}

The firm is something more than a mere combination of tangible and intangible resources. A firm is the structure which brings together the development of complex patterns of interaction between these resources, which translates as specific capabilities; that is to say, skills derived from the joint exploitation of various resources which the firm could use to achieve a competitive advantage (Amit \& Schoemaker, 1993). In this 
Navarro-García, A., Rey-Moreno, M. \& Pires de Lima, P.DA.B. (2018) Competitive Advantages as a Complete Mediator Variable in Strategic Resources, Dynamic Capabilities and Performance Relations in the Car Sales Sector. Journal of Business, Universidad del Pacífico (Lima, Peru) Vol.10(1): 24-37

context, the competitiveness generated in the last decades has forced organizations to renovate, adapt and reconfigure their resources and capabilities at the rhythm of the market, being especially necessary in complex and constantly changing environments (Makkonen, Pohjola, Olkkonen, \& Koponen, 2014). Thus emerges the dynamic capabilities focus -DCV- as a way of adapting the static character of the RBV to the dynamism of the markets (Eisenhardt \& Martin, 2000). Therefore, the concept of dynamic capacity appears not so much in opposition to the RBV, but as its extension and complement.

The definition of dynamic capabilities is the skill of the organization to integrate, construct and reconfigure its competences and align them with the market changes (Teece, Pisano, \& Shuen, 1997). These capabilities are the ones which present the greatest degree of combination of knowledge in the organization, their nature being evolutionary, facilitating the absorption, integration and reconfiguration of new knowledge in accordance with the market's dynamic (Winter, 2003).

Furthermore, they are very difficult to replicate as they have distinctive components for each organization. The development of dynamic capabilities enables the organizations to adapt themselves permanently to the demands and changes of the environment, situating the firm in an advantageous position compared to its competitors regarding the generation of value, the achievement of profits and competence in costs (Vivas López, 2005). These arguments bring about the following research hypothesis:

H4: Dynamic capabilities have a positive and direct effect on the generation of competitive advantages.

On the other hand, these dynamic capabilities can directly influence business results, absorbing even the effect that strategic resources can have on results (Lin \& Wu, 2014). That said, what is normal is that when the firm competes in dynamic markets subject to complex and constantly changing environments, the business result is not the end in itself. The aim is rather the positioning that the firm wishes to have in the industry that the firm competes in, in such a way that the orientation of the dynamic capabilities will be toward the achievement of competitive advantages and not toward the result in itself (Wilden et al., 2013). These arguments lead to the proposal of the following hypothesis:

H5: Dynamic capabilities positively influence, although indirectly through competitive advantages, business results.

\section{Competitive Advantages}

Competitive advantage is a term generally used to describe the relative performance of the firm compared to the competition in a specific market environment (Peteraf \& Barney, 2003). This advantage derives from the asymmetry observed between different 
Navarro-García, A., Rey-Moreno, M. \& Pires de Lima, P.DA.B. (2018) Competitive Advantages as a Complete Mediator Variable in Strategic Resources, Dynamic Capabilities and Performance Relations in the Car Sales Sector. Journal of Business, Universidad del Pacífico (Lima, Peru) Vol.10(1): 24-37

firms belonging to the same sector of activity which enables some of them to be more competitive than their competitors (Ariyawardana, 2003). For this situation to occur, what is usually necessary is to generate greater value in their customers than their rivals do (Kaleka, 2002).

Competitive advantages are the consequence of business strategy, fruit of the use of the organization's resources and capabilities. This situation enables the reduction of costs, the exploitation of market opportunities and the neutralization of competitive threats (Newbert, 2008). This differentiated positioning endows the firm with a greater likelihood of obtaining good economic and non-economic results compared to the competition and must be the main aim of organizations. This objective is especially necessary in dynamic and changing markets (Pezeshkan, Fainshmidt, Nair, Frazier, \& Markowski, 2016), as takes place in the present research. These arguments lead to the proposal of the following hypothesis:

H6: The generation of competitive advantages will directly and positively influence business results.

Figure 1 reflects the relations between the variables included in the research. The evaluation of the direct effect of strategic resources and capabilities on the result demonstrates the mediator effect of competitive advantages in the strategic resourcesdynamic capabilities and performance relations.

Fig. 1. Graphical description of the model.

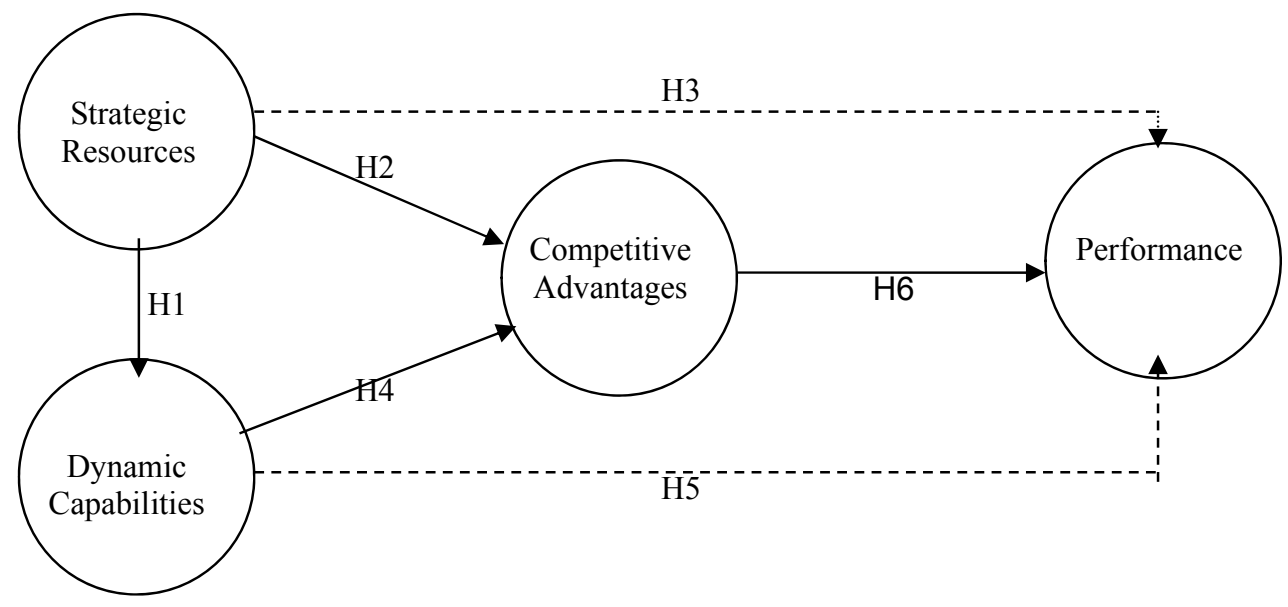


Navarro-García, A., Rey-Moreno, M. \& Pires de Lima, P.DA.B. (2018) Competitive Advantages as a Complete Mediator Variable in Strategic Resources, Dynamic Capabilities and Performance Relations in the Car Sales Sector. Journal of Business, Universidad del Pacífico (Lima, Peru) Vol.10(1): 24-37

\section{Method}

\section{Sample and Data Analysis}

Having proposed the conceptual model, the process for collecting the information took place in three phases: a) the elaboration of a prototype questionnaire from the premises of the RBV and of the DCV, and the help of 11 experts, all of them graduates in areas related with business sciences; $b$ ) the prototype questionnaire was submitted to a pretest with the help of 10 professionals of the sector of the sale of new cars in Portugal; c) then, addressed to the manager, the emailing of the questionnaire took place - this questionnaire being adapted to the reality of the sector and perfectly structured - - to all (502 establishments) of the sales points of new cars existing in Portugal.

Afterward, three more mailings were simple reminders. Diverse contacts by phone requested the manager contacted to respond to the questionnaire. 89 completed questionnaires were received - a response rate of $17.7 \%$. This result is within the acceptable range of 15 to $20 \%$ (Menon, Bharadwaj, \& Howell, 1996).

Structural equation modeling via PLS (partial least squares) is the choice of method for the data analysis and for assessing the relationships between constructs, taking into account the characteristics of the model (predictive) and the sample (fewer than 250 subjects) (Reinartz, Haenlein, \& Henseler, 2009). The empirical analysis uses the SmartPLS 3.2.6 statistics package.

\section{Measurement Scales}

The defining of the measurement scales, with the adaptations necessary to the reality of the sector developed in the pretest, considered the previous contributions of Barney (2001) related to strategic resources, of Winter (2003) in the configuration of dynamic capabilities, and of Kaleka (2002), Newbert (2008) and Morgan (2012) in the defining of competitive advantages and performance.

More specifically, the consideration was of: (a) 17 strategic resources: installations and equipment -5 items-; stocks -2 items-; availability of financial means -1 item; knowledge -3 items-; professional experience -3 items- and the training level of the human capital 3 items; (b) four types of dynamic capabilities associated with the functionality of the sales point to satisfy the needs which constantly emerge, and related to the efficiency and the level of performance of the workshop, to the versatility of the sales team in its contact and communication with customers and to the location, ease of access, of parking and of visibility; (c) three large groups of competitive advantages: those associated with costs -11 items-, with differentiation -2 items- and with the staff efficiency -3 items-; (d) 12 items define the business result, including measures connected with sales - volume and growth -, profitability and customer loyalty. 
Navarro-García, A., Rey-Moreno, M. \& Pires de Lima, P.DA.B. (2018) Competitive Advantages as a Complete Mediator Variable in Strategic Resources, Dynamic Capabilities and Performance Relations in the Car Sales Sector. Journal of Business, Universidad del Pacífico (Lima, Peru) Vol.10(1): 24-37

\section{Results}

The measurement model has been designed as a composite factor model following a reflective approach (Henseler, 2014). This design implies that the composite factor model does not impose any restrictions on the covariances between indicators of the same construct, and composites are formed as linear combinations of their respective indicators. In addition, the orientation of the model used is toward prediction. The basis of its assessment must be reliability and validity (Roldán \& Sánchez-Franco, 2012). In this vein, the loadings of both indicators and dimensions exceed the 0.70 threshold (table 1). Consequently, the indicators and dimensions are reliable. The constructs and dimensions present high internal consistency, as their composite reliability indices exceed 0.7 . In addition, an achievement of the convergent validity for all latent variables exists because the average variance extracted (AVE) ratios surpass the 0.5 benchmark (Table 1).

Table 2 shows the discriminant validity. According to the Fornell-Larcker criterion, the square root of the AVE of each latent construct is greater than its correlations with any other latent variable (Fornell \& Larcker, 1981). Furthermore, we used the heterotraitmonotrait (HTMT) ratio of correlations (Henseler, Ringle, \& Sarstedt, 2015). In this respect, all the values are under 0.85 , ensuring that the main constructs measure different aspects.

To compare the proposed hypotheses, an assessment of the precision and stability of the estimations obtained is necessary. Following Hair, Hult and Ringle (2013), the use made of bootstrapping (5000 resamples; one-tailed Student's t distribution with $(n-1)$ degrees of freedom) has been to generate standard errors and t-statistics, where $n$ is the number of subsamples to calculate the significance of the path coefficients. From these levels, the significance of the structural routes is evident and, therefore, the support or non-support of the hypotheses (Table 3). Confirmation exists, with important levels of significance, of all the hypotheses proposed in the research.

Table 1. Evaluation of measurement model

\begin{tabular}{|c|c|c|c|c|c|c|c|}
\hline \multirow[b]{2}{*}{$\begin{array}{l}\text { CONSTRUCT/Indicat } \\
\text { or }\end{array}$} & \multicolumn{7}{|c|}{ Total Sample; $\mathbf{n = 8 9}$} \\
\hline & $\begin{array}{c}\text { Factor } \\
\text { load }\end{array}$ & $\begin{array}{c}\text { Composited } \\
\text { reliability } \\
\left(\rho_{c}\right)\end{array}$ & $\begin{array}{l}\text { Average } \\
\text { variance } \\
\text { extracte } \\
\text { d (AVE) } \\
\end{array}$ & $\begin{array}{l}\text { CONSTRUCT/Indicat } \\
\text { or } \\
\end{array}$ & $\begin{array}{l}\text { Facto } \\
\text { r load }\end{array}$ & $\begin{array}{c}\text { Composited } \\
\text { reliability } \\
\left(\rho_{c}\right)\end{array}$ & $\begin{array}{l}\text { Average } \\
\text { variance } \\
\text { extracte } \\
\text { d (AVE) } \\
\end{array}$ \\
\hline $\begin{array}{lr}\text { Strategic } & \text { Resources } \\
\text { (First r r } & \text { order } \\
\text { reflective construct) }\end{array}$ & & 0.944 & 0.702 & $\begin{array}{c}\text { Advantages } \\
\text { Competitive (First } \\
\text { order reflective } \\
\text { construct) }\end{array}$ & & 0.938 & 0.689 \\
\hline REC01 & 0.735 & & & ADVC01 & 0.778 & & \\
\hline REC02 & 0.761 & & & ADVC02 & 0.735 & & \\
\hline REC03 & 0.728 & & & ADVC03 & 0.744 & & \\
\hline REC04 & 0.716 & & & ADVC04 & 0.762 & & \\
\hline REC05 & 0.710 & & & ADVC05 & 0.780 & & \\
\hline REC06 & 0.723 & & & ADVC06 & 0.760 & & \\
\hline REC07 & 0.779 & & & ADVC07 & 0.751 & & \\
\hline REC08 & 0.771 & & & ADVC08 & 0.772 & & \\
\hline REC09 & 0.747 & & & ADVC09 & 0.724 & & \\
\hline REC10 & 0.783 & & & ADVC10 & 0.784 & & \\
\hline REC11 & 0.730 & & & ADVC11 & 0.785 & & \\
\hline REC12 & 0.741 & & & ADVC12 & 0.736 & & \\
\hline REC13 & 0.818 & & & ADVC13 & 0.712 & & \\
\hline REC14 & 0.736 & & & ADVC14 & 0.796 & & \\
\hline REC15 & 0.792 & & & ADVC15 & 0.742 & & \\
\hline REC16 & 0.760 & & & ADVC16 & 0.796 & & \\
\hline REC17 & 0.770 & & & & & & \\
\hline
\end{tabular}


Navarro-García, A., Rey-Moreno, M. \& Pires de Lima, P.DA.B. (2018) Competitive Advantages as a Complete Mediator Variable in Strategic Resources, Dynamic Capabilities and Performance Relations in the Car Sales Sector. Journal of Business, Universidad del Pacífico (Lima, Peru) Vol.10(1): 24-37

\begin{tabular}{cccccc}
\hline $\begin{array}{c}\text { Dinamic Capabilities } \\
\text { order }\end{array}$ & First $\begin{array}{c}\text { Performance (First } \\
\text { order reflective } \\
\text { reflective construct) }\end{array}$ & 0.910 & 0.718 & 0.866 & 0.760 \\
DCAP01 & 0.856 & PERF01 & 0.763 & \\
DCAP02 & 0.855 & PERF02 & 0.723 \\
DCAP03 & 0.877 & PERF03 & 0.717 \\
DCAP04 & 0.799 & PERF04 & 0.882 \\
& & PERF05 & 0.747 \\
& & PERF06 & 0.896 \\
& & PERF07 & 0.793 \\
& & PERF08 & 0.825 \\
& & PERF09 & 0.785 \\
& & PERF10 & 0.723 \\
\end{tabular}

The Stone-Geisser (Q2) test used is a criterion to measure the predictive relevance of the dependent constructs. According to Chin (2010), if Q2>0, the construct has predictive relevance. In this study's model all the $Q 2$ values of the dependent constructs display values above 0.22 (Table 3), which explains why the model has predictive relevance.

Table 2. Discriminant Validity

\begin{tabular}{|l|cccc|}
\hline \multirow{2}{*}{\multicolumn{1}{|c|}{ Construct }} & \multicolumn{4}{|c|}{ Fornell-Larker Criterion } \\
\cline { 2 - 5 } & 1 & 2 & 3 & 4 \\
\hline 1. Dynamic Capabilities & $\mathbf{0 . 8 4 7}$ & $\mathbf{0 . 8 7 2}$ & \\
2. Performance & 0.226 & 0.286 & $\mathbf{0 . 8 3 8}$ & \\
3. Strategic Resources & 0.730 & 0.392 & 0.574 & $\mathbf{0 . 8 3 0}$ \\
4. Competitive Advantages & 0.562 & &
\end{tabular}

Note: Diagonal elements (bold) are the square root of the variance shared between the constructs and their measures (average variance extracted). Off-diagonal elements are the correlations among constructs

\begin{tabular}{|l|ccc|}
\hline \multicolumn{1}{|c|}{ Construct } & \multicolumn{4}{c|}{ Heterotrait Monotrait Ratio (HTMT) } \\
\cline { 2 - 4 } & 1 & 2 & 3 \\
\hline 1. Dinamic Capabilities & & & \\
2. Performance & 0.288 & & \\
3. Strategic Resources & 0.802 & 0.328 & 0.584 \\
4. Advantages Competitive & 0.584 & 0.424 & \\
\hline
\end{tabular}

Table 3. Direct and indirect effects on endogenous variables

\begin{tabular}{|c|c|c|c|}
\hline \multirow[b]{2}{*}{ Hypothesis } & \multicolumn{3}{|c|}{$\begin{array}{c}\text { Total sample; } n=89 \\
\text { Effects on endogenous variables }\end{array}$} \\
\hline & Direct effect & $\begin{array}{c}\text { t value } \\
\text { (bootstrap }\end{array}$ & $\begin{array}{c}\text { Explained } \\
\text { variance }\end{array}$ \\
\hline Dynamic Capabilities & \multicolumn{3}{|c|}{$\mathrm{R}^{2}=0.532 ; \mathrm{Q}^{2}=0.371$} \\
\hline H1: Strategic Resources $>$ Dynamic Capabilities & $\beta 1=0.729 * * *$ & 11.095 & $53.22 \%$ \\
\hline Competitive Advantage & \multicolumn{3}{|c|}{$\mathrm{R}^{2}=0.374 ; \mathrm{Q}^{2}=0.343$} \\
\hline H2: Strategic Resources $>$ Competitive Advantages & $\beta 2=0.352 * *$ & 2.329 & $20.20 \%$ \\
\hline H4: Dynamic Capabilities > Competitive Advantages & $\beta 4=0.305^{*}$ & 1.941 & $17.14 \%$ \\
\hline Performance & \multicolumn{3}{|c|}{$\mathrm{R}^{2}=0.261 ; \mathrm{Q}^{2}=0.228$} \\
\hline H3: Strategic Resources $>$ Performance & $\beta 3=0.133 \mathrm{~ns}$ & 0.552 & $3.80 \%$ \\
\hline H5: Dynamic Capabilities > Performance & $\beta 5=0.070 \mathrm{~ns}$ & 0.265 & $1.58 \%$ \\
\hline H6: Advantages Competitive $>$ Performance & $\beta 6=0.355^{*}$ & 1.718 & $13.92 \%$ \\
\hline
\end{tabular}


Navarro-García, A., Rey-Moreno, M. \& Pires de Lima, P.DA.B. (2018) Competitive Advantages as a Complete Mediator Variable in Strategic Resources, Dynamic Capabilities and Performance Relations in the Car Sales Sector. Journal of Business, Universidad del Pacífico (Lima, Peru) Vol.10(1): 24-37

\begin{tabular}{|l|ccc|}
\hline & Indirect effect & $\begin{array}{c}\text { t value } \\
\text { (bootstrap) }\end{array}$ & $\begin{array}{c}\text { Explained } \\
\text { variance }\end{array}$ \\
\hline Strategic Resources > Competitive Advantages $(\beta 1 * \beta 4)$ & $0.223 *$ & 1.926 & $9.15 \%$ \\
Strategic Resources > Performance $(\beta 1 * \beta 4 * \beta 6 ; \beta 2 * \beta 6)$ & $0.153 \mathrm{~ns}$ & 0.813 & $3.44 \%$ \\
Dynamic Capabilities > Performance $(\beta 4 * \beta 6)$ & $0.108 \mathrm{~ns}$ & 1.295 & $2.38 \%$ \\
$* * * \mathrm{p}<0.001$, (based on $\mathrm{t}(4999)$, one-tailed test); $\mathrm{t}(0.05,4999)=1.645, \mathrm{t}(0.01 .4999)=2.327, \mathrm{t}(0.001,4999)=3.092$ \\
Bootstrapping based on $\mathrm{n}=5000$ subsamples; $\mathrm{ns}=$ not significant
\end{tabular}

\section{Discussion and Conclusions}

Concentrating on the relationships between the variables and taking the global model as a reference, the study offers certain contributions. First, the results show that the possession and use of strategic resources, both tangible and intangible, are fundamental for the generation of capabilities which, dynamically, enable the organization to compete in turbulent environments, adapting itself to their constant changes (Makadok, 2001).

This result confirms hypothesis $\mathrm{H} 1$ and shows that the precepts of RBV are perfectly applicable in dynamic sectors, such as is the case in the sale of new cars in Portugal, whenever the consideration exists that the mere possession of strategic resources is not an end in itself, the aim being rather to generate dynamic capabilities (Helfat \& Peteraf, 2003). When this generation takes place, these strategic resources help the organization to create competitive advantages either in costs, differentiation or the efficiency of human resources, confirming $\mathrm{H} 2$.

This situation is due to strategic resources, which not all the organizations within the sector have, enabling the firm to react in time in the face of threats and existing opportunities, correcting its weaknesses and reinforcing its strength. This appropriate strategic orientation endows the firm with a differentiated positioning in the market and is an essential source for the generating of sustainable competitive advantages (Kozlenkova, Samaha, \& Palmatier, 2014).

These reasons also explain that the use of strategic resources in dynamic environments must not center itself on the business results, but on the generation of dynamic capabilities and the achievement of competitive advantages. This result confirms $\mathrm{H} 3$ and shows the indirect effect - although positive- of strategic resources on business results. In this sense, to adopt a strategic perspective oriented exclusively toward the result reflects a myopic view of the organization, centered on the short term. This view can be erroneous in the medium and long term if a recognition of the market does not exist through the generating of value for the customers (Teece, 2007).

Second, in dynamic and turbulent environments, the development of specific skills to compete in the market is essential to generate value in the customers, either through products and services which have a high quality-price relation or with a level of differentiation which enables a premium positioning in the market (Vivas López, 2005).

This fact explains the direct positive effect of dynamic capabilities on the generation of competitive advantages, confirming $\mathrm{H} 4$. That said, to recognize that these dynamic capabilities are not standard or universal but depend on the sector in which the firm competes is necessary. So, in the present research what is essential to adapt to the dynamism of the industry - the sale of new cars - is to generate dynamic capabilities associated with the functionality of the sales point to satisfy the needs which are constantly emerging, related to the efficiency and level of performance of the workshop, to the versatility of the sales team in contact and communication with the customers and to the location -ease of access, of parking and visibility. In any case, what is clear is that 
Navarro-García, A., Rey-Moreno, M. \& Pires de Lima, P.DA.B. (2018) Competitive Advantages as a Complete Mediator Variable in Strategic Resources, Dynamic Capabilities and Performance Relations in the Car Sales Sector. Journal of Business, Universidad del Pacífico (Lima, Peru) Vol.10(1): 24-37

the achieving of competitive advantages and not the business result in itself must prevail in the organization's strategic orientation (Wilden, Gudergan, Nielsen, \& Lings, 2013), explaining the non-confirmation of $\mathrm{H} 5$. This orientation can avoid the firm being displaced in the market, making their short-term myopia cause the firm competitive disadvantages in costs or differentiation in the medium and long term.

Third, in dynamic and changing environments, the generation of competitive advantages from the use of strategic resources and available dynamic capabilities must be the epicenter of the organization's strategic orientation (Newbert, 2008). These advantages of costs, differentiation or efficiency of human resources will be essential for the sales to continue growing, the customers to become loyal and the organization's profitability to increase, and will positively influence the business results. These reasons explain the confirmation of $\mathrm{H} 6$. In this sense, the present research shows the essential role competitive advantages play as a mediator variable in the relation between strategic resources, dynamic capabilities and business results, and is one of the major contributions of the study.

To sum up, this study represents an important advance in the literature on the strategic management of organizations. Taking the RBV and the DCV as an orientation, the study explicitly validates the direct interrelationships between strategic resources, dynamic capabilities, competitive advantages and performance. Additionally, this work shows the indirect effect, through competitive advantages, of strategic resources and dynamic capabilities on business results.

This study has some limitations. First, this study is synchronic, because this research takes information from a specific moment in time. Scholars should engage in a longitudinal study to analyze the strategic resources-dynamic capabilities- competitive advantages-performance relationships. Second, the sample comes from a single country -Portugal. To make the previous conclusions expandable, firms from a wider geographic area should feature in the analysis.

\section{References}

Amit, R., \& Schoemaker, P. J. (1993). Strategic assets and organizational rent. Strategic Management Journal, 14(1), 33-46.

Ariyawardana, A. (2003). Sources of competitive advantage and firm performance: The case of Sri Lankan value-added tea producers. Asia Pacific Journal of Management, 20(1), 73-90.

Barney, J. (1991). Firm resources and sustained competitive advantage. Journal of Management, 17(1), 99-120.

Barney, J. B. (2001). Resource-based theories of competitive advantage: A ten-year retrospective on the resource-based view. Journal of Management, 27(6), 643-650.

Barney, J. B., \& Arikan, A. M. (2001). The resource-based view: Origins and implications. Handbook of Strategic Management, 124-188.

Barney, J. B., Ketchen, D. J., \& Wright, M. (2011). The future of resource-based theory revitalization or decline? Journal of Management, 37(5), 1299-1315. 
Navarro-García, A., Rey-Moreno, M. \& Pires de Lima, P.DA.B. (2018) Competitive Advantages as a Complete Mediator Variable in Strategic Resources, Dynamic Capabilities and Performance Relations in the Car Sales Sector. Journal of Business, Universidad del Pacífico (Lima, Peru) Vol.10(1): 24-37

Capron, L., \& Hulland, J. (1999). Redeployment of brands, sales forces, and general marketing management expertise following horizontal acquisitions: A resource-based view. Journal of Marketing, 63(2), 41-54.

Chin, W. W. (2010). How to write up and report PLS analyses. In Handbook of Partial Least Squares (pp. 655-690). Springer Berlin Heidelberg.

Crook, T. R., Ketchen, D. J., Combs, J. G., \& Todd, S. Y. (2008). Strategic resources and performance: a meta-analysis. Strategic Management Journal, 29(11), 1141-1154.

Dhanaraj, C., \& Beamish, P. W. (2003). A resource-based approach to the study of export performance. Journal of Small Business Management, 41(3), 242-261.

Eisenhardt, K. M., \& Martin, J. A. (2000). Dynamic capabilities: what are they? Strategic Management Journal, 21(10-11), 1105-1121.

Fornell, C., \& Larcker, D. F. (1981). Evaluating structural equation models with unobservable variables and measurement error. Journal of Marketing Research, 18(1), 39-50.

Grant, R. M. (1996). Toward a knowledge-based theory of the firm. Strategic Management Journal, 17(2), 109-122.

Helfat, C. E., \& Peteraf, M. A. (2003). The dynamic resource-based view: Capability lifecycles. Strategic Management Journal, 24(10), 997-1010.

Hair, J. F. Jr., Hult, G. T. M., Ringle, C., \& Sarstedt, M. (2013). A primer on partial least squares structural equation modeling (PLS-SEM). Thousand Oaks, CA: SAGE Publications, Incorporated.

Henseler, J. (2014). Common factor models, composite models, and formative measurement: Their nature, application, and testing. Lecture at University of Seville. November 20.

Henseler, J., Ringle, C. M., \& Sarstedt, M. (2015). A new criterion for assessing discriminant validity in variance-based structural equation modeling. Journal of the Academy of Marketing Science, 43(1), 115e135.

Kaleka, A. (2002). Resources and capabilities driving competitive advantage in export markets: guidelines for industrial exporters. Industrial Marketing Management, 31(3), 273-283.

Kozlenkova, I. V., Samaha, S. A., \& Palmatier, R. W. (2014). Resource-based theory in marketing. Journal of the Academy of Marketing Science, 42(1), 1-21.

Lin, Y., \& Wu, L. Y. (2014). Exploring the role of dynamic capabilities in firm performance under the resource-based view framework. Journal of Business Research, 67(3), 407413.

Makadok, R. (2001). Toward a synthesis of the resource-based and dynamic-capability views of rent creation. Strategic Management Journal, 22(5), 387-401.

Makkonen, H., Pohjola, M., Olkkonen, R., \& Koponen, A. (2014). Dynamic capabilities and firm performance in a financial crisis. Journal of Business Research, 67(1), 27072719. 
Navarro-García, A., Rey-Moreno, M. \& Pires de Lima, P.DA.B. (2018) Competitive Advantages as a Complete Mediator Variable in Strategic Resources, Dynamic Capabilities and Performance Relations in the Car Sales Sector. Journal of Business, Universidad del Pacífico (Lima, Peru) Vol.10(1): 24-37

Menon, A., Bharadwaj, S. G., \& Howell, R. (1996). The quality and effectiveness of marketing strategy: Effects of functional and dysfunctional conflict in intraorganizational relationships. Journal of the Academy of Marketing Science, 24(4), 299-313.

Morgan, N. A. (2012). Marketing and business performance. Journal of the Academy of Marketing Science, 40(1), 102-119.

Netland, T., \& Aspelund, A. (2013). Company-specific production systems and competitive advantage: a resource-based view on the Volvo Production System. International Journal of Operations \& Production Management, 33(11/12), 1511-1531.

Newbert, S. L. (2008). Value, rareness, competitive advantage, and performance: a conceptual-level empirical investigation of the resource-based view of the firm. Strategic Management Journal, 29(7), 745-768.

Nicolini, M., Scarpa, C., \& Valbonesi, P. (2016). Determinants of state aid to firms: the case of the European automotive industry. Industrial and Corporate Change, dtw023.

Peteraf, M. A., \& Barney, J. B. (2003). Unraveling the resource-based tangle. Managerial and Decision Economics, 24(4), 309-323.

Pezeshkan, A., Fainshmidt, S., Nair, A., Frazier, M. L., \& Markowski, E. (2016). An empirical assessment of the dynamic capabilities-performance relationship. Journal of Business Research, 69(8), 2950-2956.

Powalla, C. (2012). Practical implications of the resource-based view. Zeitschrift für Betriebswirtschaft, 82(4), 335-359.

Reinartz, W., Haenlein, M., \& Henseler, J. (2009). An empirical comparison of the efficacy of covariance-based and variance-based SEM. International Journal of Research in Marketing, 26(4), 332-344.

Roldán, J. L., \& Sánchez-Franco, M. J. (2012). Variance-based structural equation modeling: guidelines for using partial least squares. Information Systems Research, in M.Mora, O.Gelman, A.L. Steenkamp, \& M. Raisinghani (Eds.) Research Methodologies, Innovations and Philosophies in Software Systems Engineering and Information Systems, pp.193-221. Hershey (PA), IGI Global.

Teece, D. J., Pisano, G., \& Shuen, A. (1997). Dynamic capabilities and strategic management. Strategic Management Journal, 18(7), 509-533.

Teece, D.J. (2007). Explicating dynamic capabilities: the nature and microfoundations of (sustainable) enterprise performance. Strategic Management Journal, 28(13), 13191350.

Vivas López, S. (2005). Competitive advantage and strategy formulation: The key role of dynamic capabilities. Management Decision, 43(5), 661-669.

Wilden, R., Gudergan, S. P., Nielsen, B. B., \& Lings, I. (2013). Dynamic capabilities and performance: strategy, structure and environment. Long Range Planning, 46(1), 72-96.

Winter, S. G. (2003). Understanding dynamic capabilities. Strategic Management Journal, 24(10), 991-995. 
Navarro-García, A., Rey-Moreno, M. \& Pires de Lima, P.DA.B. (2018) Competitive Advantages as a Complete Mediator Variable in Strategic Resources, Dynamic Capabilities and Performance Relations in the Car Sales Sector. Journal of Business, Universidad del Pacífico (Lima, Peru) Vol.10(1): 24-37

Wu, L. Y. (2010). Applicability of the resource-based and dynamic-capability views under environmental volatility. Journal of Business Research, 63(1), 27-31. 